\title{
Analysis of Teacher Difficulties in Online Learning on Mathematics Subjects
}

\author{
Yuyun Nailufar*, Safruddin, Moh. Irawan Zain \\ Elementary School Teacher Education Study Program, FKIP, University of Mataram, Jl. \\ Majapahit No 62 Mataram, 83125, Indonesia \\ *Corresponding Author e-mail: nailufaryuyun3@gmail.com
}

Received: November 2021; Revised: November 2021; Published: December 2021

\begin{abstract}
The COVID-19 pandemic has had an impact on various fields in the world, without exception in the field of education. This situation causes the change in learning which is usually face-to-face in the classroom to be carried out at home, namely by online learning. During online learning, many students find it difficult to learn mathematics online. This study aims to determine the difficulties of teachers in online learning at SDN 32 Cakranegara in Mathematics. This study is a qualitative descriptive study, the population in this study were all grade III-VI teachers at SDN 32 Cakranegara, the sampling technique used cluster random sampling. The research sample selected was 4 class teachers. The data collection instruments used interview questionnaires, observation sheets, and documentation studies. Data analysis techniques consist of data reduction, data presentation, and Conclusion Drawing/Verification. The results showed that teachers experienced difficulties in online learning, namely: learning planning in the technique of determining learning methods, making learning media and determining 3 types of affective, cognitive and psychomotor assessments. Difficulties in implementing learning in preliminary activities are preparing students psychologically and physically and providing motivation, core activities are observing, asking questions, digging and collecting information and communicating and closing activities on feedback, follow-up and information on further activities. And the difficulty of providing an assessment in applying 3 types of affective assessment on observation, selfassessment, assessment between students and journals. Cognitive on written tests, oral tests and assignments and psychomotor on practice, projects, and portfolios during online learning in Mathematics.
\end{abstract}

Keywords: Teacher difficulties, online learning, Mathematichs

How to Cite: Nailufar, Y., Safruddin, S., \& Zain, M. (2021). Analysis of Teacher Difficulties in Online Learning on Mathematics Subjects. Prisma Sains : Jurnal Pengkajian Ilmu dan Pembelajaran Matematika dan IPA IKIP Mataram, 9(2), 280-288. doi:https://doi.org/10.33394/j-ps.v9i2.4376

\section{INTRODUCTION}

Mathematics is one of the fields of study that is taught in schools, both Elementary Schools, Junior High Schools and General High Schools. A teacher who will teach mathematics to students, should know and understand the object to be taught, namely mathematics. The mathematics chosen is mathematics that can organize reasoning, shape personality, instill values, solve problems, and perform certain tasks (Rahmah, 2018).

Mathematics teaching skills are not easily obtained by a Mathematics teacher, this is the problem why Mathematics is difficult. At the beginning of 2020, the difficulty in learning Mathematics was exacerbated by a major disaster that hit Indonesia, namely the Corona virus pandemic that plagued all regions in Indonesia. Due to the Covid-19 pandemic situation, the Indonesian government has implemented physical distancing for citizens (Ramdani, et al., 2020). The same is true in the city of Mataram.

Based on the results of observations and interviews at SDN 32 Cakranegara, there are difficulties in terms of planning online learning, teachers have difficulty in determining 
learning methods, making learning media and determining 3 types of assessments used in online learning, then difficulties in implementing online learning, namely: teachers have difficulty conveying preliminary, core and closing activities as well as final difficulties in providing assessments during online learning, namely affective, cognitive and psychomotor assessments, where teachers have difficulty applying 3 assessments at once in online learning.

Difficulty comes from the word difficult which means a difficult situation, something difficult, difficulty, difficulty (https://kbbi.kemendikbud.go.id/entri/difficulty). Djamarah (2000) states that the teacher in the community's view is a person who carries out education in certain places, not necessarily in a formal institution. It's just that because of online learning, the implementation time encounters difficulties. These difficulties are in planning, implementing and evaluating.

Planning learning has components that must be prepared according to Permendikbud Number 65 of 2013 concerning Standards for the Primary and Secondary Education Process, including: preparing materials, determining learning methods, selecting media, learning tools and sources, determining the type of assessment, compiling assessment instruments and scoring guidelines. and designing student worksheets.

Carrying out learning is the implementation of RPP, according to Permendikbud No. 65 of 2013 concerning Standards for Primary and Secondary Education Processes. The implementation of learning includes: Preliminary activities, core activities and closing activities.

The assessment technique used in authentic assessment, both for assessing attitudes, knowledge, and skills, is described in Permendikbud RI No. 66 of 2013 as follows: Attitude competency assessment, namely: observation, self-assessment, peer evaluation by students and journals. Knowledge competency assessment, namely: written test, oral test, and assignment. And skill competency assessment, namely: practice, project, and portfolio assessment.

\section{METHOD}

The type of research used is qualitative research. The research approach used is qualitative research with a descriptive approach. According to Moleong (2014) said that qualitative research is research that intends to understand the phenomenon of what is assessed by research subjects such as behavior, perception, motivation, action and others. In this study, the researcher took a population of class teachers at SDN 32 Cakranegara starting from grades III-VI, the sampling technique used cluster random sampling. The research sample selected was 4 class teachers.

Data collection techniques are observation, interviews and documentation. Observations used by researchers are passive participation, ie researchers will go to the field, but researchers are not involved in the activities of the informants. The type of interview used is a semi-structured interview, namely the type of interview that is included in the indept interview category, and the last data collection technique is documentation, documentation is a record of events that have passed, documents can be in the form of writing, pictures, or monumental works from somebody. According to Moleong (2014). The data analysis method uses an interactive model data analysis technique from Miles and Huberman consisting of data reduction, data presentation, and Conclusion Drawing / Verification. Test the credibility of the data or test the trustworthiness of the research data presented by the researcher so that the results of the research carried out do not doubt as a scientific work. Thus the data analysis used the observers triangulation method. Because the triangulation used in this study is a source of data and methods. Triangulation of data sources is done by asking for the truth of certain data or confirming between one source and another at SDN 32 Cakranegara. While the triangulation method is also done by comparing data and information from observations, 
interviews, archive documentation and questionnaire data related to these data. The analytical model is presented in Figure 1.

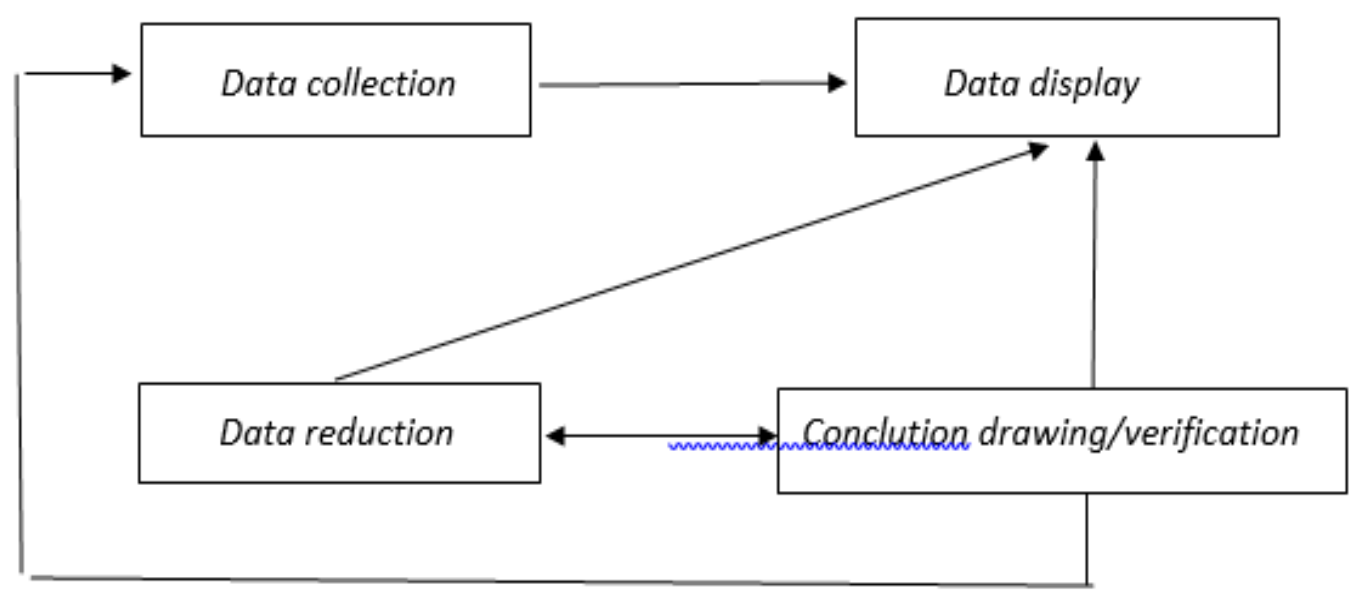

Figure 1. Analysis model.

\section{RESULTS AND DISCUSSION}

Teacher Difficulties in Planning Online Learning in Mathematics Subjects

Table 1. Teacher Difficulties in Planning Online Learning in Mathematics Subjects

\begin{tabular}{cccccc}
\hline Teacher & \multicolumn{5}{c}{ Learning Planning Components } \\
\cline { 2 - 6 } Class & $\begin{array}{c}\text { Prepare } \\
\text { Material }\end{array}$ & $\begin{array}{c}\text { Determine } \\
\text { Method } \\
\text { Learning }\end{array}$ & $\begin{array}{c}\text { Election } \\
\text { Media } \\
\text { Tools and } \\
\text { Resources }\end{array}$ & $\begin{array}{c}\text { Determining the } \\
\text { Type of Assessment } \\
\text { and Scoring } \\
\text { Guidelines }\end{array}$ & $\begin{array}{c}\text { Designing } \\
\text { Student } \\
\text { Worksheet }\end{array}$ \\
\hline III & - & $\sqrt{ }$ & - & $\sqrt{ }$ & - \\
IV & - & $\sqrt{ }$ & $\sqrt{ }$ & $\sqrt{ }$ & - \\
V & - & $\sqrt{ }$ & $\sqrt{ }$ & $\sqrt{ }$ & - \\
VI & - & $\sqrt{ }$ & & & - \\
\hline
\end{tabular}

Information:

Sign $\sqrt{ }=$ Difficulty

Login - = No Difficulty

Based on the results of the study, 4 teachers had no difficulty in preparing online learning materials, 1 teacher had no difficulty in choosing media, tools and sources. And 4 teachers had no difficulty in designing LKPD. However, 4 teachers had difficulties in determining online learning methods, especially in the technique of determining methods during online learning, because the online learning process only uses WhatssAp, does not meet directly with students and does not use the Zoom application. Furthermore, 3 teachers have difficulty in choosing online learning media, namely difficulties in making learning videos because the online learning process uses whatsapp, so the teacher provides media in the form of a youtube link. Then the results showed that 4 teachers had difficulty in determining 3 types of assessment, namely affective, cognitive and psychomotor so that they could only apply some assessments.

This is as expressed by Usman, (2002) explains several factors that must be considered in the selection of learning methods as follows: 1. Objectives, 2. Characteristics of Students, 3. Situations and conditions/settings, 4. Personal and teacher differences. capability 5. Facilities and infrastructure (Ananda, 2019:117). In addition, there are several principles that must be considered in the selection of media, namely: first, the selection of media must be in accordance with the objectives to be achieved; second, the selection of media must be based on a clear concept; third, the selection of media must be adjusted to the style and ability of 
the teacher; fourth, the selection of media must be in accordance with the student's learning style as well as the support, facilities, and time available for learning needs (Prastowo, 2015). Based on research conducted by Ariesca, et al (2020) it was found that teachers had difficulty in determining the type of assessment due to circumstances that did not allow teachers to meet directly with students and carry out learning activities.

\section{Teacher Difficulties in Implementing Online Learning in Mathematics Subjects}

Preliminary activities

Table 2. Teacher Difficulties in Implementing Learning in Preliminary Activities

\begin{tabular}{cccccc}
\hline Teacher & \multicolumn{5}{c}{ Preliminary activities } \\
\cline { 2 - 6 } & $\begin{array}{c}\text { Preparing } \\
\text { Students } \\
\text { Psychologically } \\
\text { and Physically }\end{array}$ & $\begin{array}{c}\text { Preparing } \\
\text { Students } \\
\text { Psychologically } \\
\text { and Physically }\end{array}$ & $\begin{array}{c}\text { Asking } \\
\text { Questions }\end{array}$ & $\begin{array}{c}\text { Explaining } \\
\text { Learning } \\
\text { Objectives or } \\
\text { Basic } \\
\text { Competencies }\end{array}$ & $\begin{array}{c}\text { Explaining } \\
\text { Material Coverage } \\
\text { and Explanation } \\
\text { Description }\end{array}$ \\
\hline III & $\sqrt{ }$ & - & - & - & - \\
IV & $\sqrt{ }$ & $\sqrt{ }$ & - & - & - \\
V & $\sqrt{ }$ & $\sqrt{ }$ & - & - & - \\
VI & $\sqrt{ }$ & $\sqrt{ }$ & - & - & - \\
\hline
\end{tabular}

Information:

Sign $\sqrt{ }=$ Difficulty

Login - = No Difficulty

Based on the results of observations and interviews, 4 teachers experienced difficulties in preparing students psychologically and physically to take part in the online learning process in Mathematics, this is because the online learning process uses WhatsApp, students do not have internet and cellphone quotas and the role of parents. Furthermore, 3 teachers experienced difficulties in motivating students to learn when online learning in Mathematics subjects. This is because it is difficult to motivate students from cellphones, and do not get feedback from students because, only a few students answer and most parents hold cellphones. In asking questions that relate previous knowledge to the material to be studied during online learning in Mathematics, 4 teachers did not experience difficulties. And explain the learning objectives or basic competencies to be achieved when online learning in Mathematics subjects, 4 teachers also have no difficulty in this matter and the last is in conveying the scope of the material and explanations for the description of activities according to the syllabus when online learning in Mathematics subjects 4 people the teacher had no problems.

In a good learning process, a teacher should take the apperception step, the appreciative step in this opening is to prepare mentally so that students are able and able to receive learning material, this step is basically a step to create conditions so that the subject matter is easy to enter and stick in the brain. Sanjaya, 2006). Based on the results of research conducted by Husna, et al (2021), the results of his research indicate that $50 \%$ of Mathematics teachers have difficulty in motivating students to participate in online learning. This shows that students have less willingness to participate in online learning.

Core activities

Table 3. Teacher Difficulties in Implementing Learning in Core activities

\begin{tabular}{ccccc}
\hline Teacher Class & \multicolumn{4}{c}{ Core activities } \\
\cline { 2 - 5 } & Observe & Ask & Digging and Gathering Information & Communicate \\
\hline III & $\sqrt{ }$ & $\sqrt{ }$ & $\sqrt{ }$ & $\sqrt{ }$ \\
IV & $\sqrt{ }$ & $\sqrt{ }$ & $\sqrt{ }$ & $\sqrt{ }$ \\
V & $\sqrt{ }$ & $\sqrt{ }$ & $\sqrt{ }$ & $\sqrt{ }$ \\
VI & $\sqrt{ }$ & $\sqrt{ }$ & &
\end{tabular}


Information:

Sign $\sqrt{ }=$ Difficulty

Login - = No Difficulty

Based on the results of observations and interviews, 4 teachers had difficulty making observations on students, because they could not see the responses of students, students were less responsive, and the character of students was different this was due to the lack of interest of students in online learning, lack of facilities and infrastructure such as quotas, and mobile phones and not face to face in the learning process. Furthermore, the results showed that 4 classroom teachers had difficulties for students to ask questions, especially on the material that had been explained by the teacher, students sometimes asked for clear information, only a few students asked questions related to their difficulties, and none of the students asked the same questions. very. This is due to the lack of interest of students in online learning, and the facilities and infrastructure owned by students. Then 4 classroom teachers had difficulty in trying to get students to explore and collect information from various sources during online learning on Mathematics subjects, this was because information about learning materials was not conveyed to students, there was no initiative from students, and students did not able to gather information. And finally, 4 classroom teachers had difficulty in trying to get students to communicate the results obtained from digging and collecting information during online learning in Mathematics. The difficulty is because students are not able to communicate the results by making videos of the material, besides that students are not able to collect information so they cannot communicate the results. This is because there is no quota and online learning using WhatsApp.

In asking questions the teacher can do the following; 1. Intensify observing activities closely; 2. Create an atmosphere of warmth and enthusiasm; 3 . Increase interest and courage to ask questions; 4. Sometimes it is necessary to give a reward; 5. Provide opportunities for students who never or rarely ask questions (Badar, 2014: 274). Based on research conducted by Ariesca, et al (2020) According to the confession of several teachers at the time of delivering the material there were only a few students who responded or took part in the learning that day, even though the material presented by the teacher was new material that students needed to understand. In addition, many students do not have smartphones or internet quota packages, which causes students not to get materials that are shared online.

Closing Activities

Table 4. Teacher Difficulties in Implementing Learning in Closing Activities

\begin{tabular}{ccccc}
\hline \multirow{2}{*}{ Teacher Class } & \multicolumn{4}{c}{ Closing Activities } \\
\cline { 2 - 5 } & $\begin{array}{c}\text { Finding Direct or } \\
\text { Indirect Benefits }\end{array}$ & $\begin{array}{c}\text { Giving } \\
\text { Feedback }\end{array}$ & $\begin{array}{c}\text { Doing Follow } \\
\text { Up Activities }\end{array}$ & $\begin{array}{c}\text { Informing the Planned } \\
\text { Learning Activities for the } \\
\text { Next Meeting }\end{array}$ \\
\hline III & - & $\sqrt{ }$ & $\sqrt{ }$ & $\sqrt{ }$ \\
IV & - & $\sqrt{ }$ & $\sqrt{ }$ & $\sqrt{ }$ \\
V & - & $\sqrt{ }$ & $\sqrt{ }$ & $\sqrt{ }$ \\
VI & - & $\sqrt{ }$ &
\end{tabular}

Information:

Sign $\sqrt{ }=$ Difficulty

Login - = No Difficulty

Based on the results of observations and interviews, 4 teachers had no difficulty in finding direct or indirect benefits, from the learning outcomes that had taken place in online learning in Mathematics. And 1 teacher had no difficulty in informing the activity plan for the next meeting. In terms of providing feedback on the learning process and results during online learning in Mathematics 4, class teachers have difficulty, because they only get 
feedback from some students due to online learning using WhatsApp, and depending on the student quota.

Then in carrying out follow-up activities in the form of giving assignments, both individual and group assignments when online learning in Mathematics 4 subjects, teachers have difficulty with this, this is because they never give group assignments because it will take time during online learning, besides that Group work will result in students crowding so that the teacher only gives individual assignments to students. And the last is in informing the plan of learning activities for the next meeting during online learning in Mathematics. 3 teachers have difficulty informing the next activity plan during online learning, this is because students are less responsive during learning. Finally there are only a few students who understand the next activity.

Learning activities for each meeting are scenarios of the teacher's steps in making students active in learning. Teachers need to get feedback, whether the goals to be achieved have been mastered by students or not, whether the process or teacher's speaking style can be understood or not. This is very necessary for the teaching improvement process that has been carried out (Sanjaya, 2013). In addition, learning activities are organized through activities: introduction, core, and closing. This activity is further elaborated into the details of exploration, elaboration, and confirmation activities, namely observing, asking questions, gathering information, associating, and communicating (Prastowo, 2015).

\section{Teacher Difficulties in Assessing Online Learning in Mathematics Subjects Attitude Competency Assessment}

Table 5. Teacher Difficulties in Attitude Assessment

\begin{tabular}{ccccc}
\hline Teacher & \multicolumn{4}{c}{ Attitude Assessment } \\
\cline { 2 - 5 } Class & Observation & Self-assessment & Assessment among & Journal \\
& & $\sqrt{ }$ & students & \\
III & $\sqrt{ }$ & $\sqrt{ }$ & $\sqrt{ }$ & - \\
IV & $\sqrt{ }$ & $\sqrt{ }$ & $\sqrt{ }$ & $\sqrt{ }$ \\
V & $\sqrt{ }$ & $\sqrt{ }$ & $\sqrt{ }$ & $\sqrt{ }$ \\
VI & $\sqrt{ }$ & &
\end{tabular}

Information:

Sign $\sqrt{ }=$ Difficulty

Login - = No Difficulty

Based on the results of observations and interviews, 4 teachers experienced difficulties in providing observational assessments during online learning in Mathematics, because the observations were carried out in the WhatsApp group, so it was difficult for teachers to make honest observations of students, because they did not meet in person. Furthermore, 4 teachers have never done self-assessment, due to time constraints and student quotas, besides that the teacher also feels that with the self-assessment in the online learning process, students will judge both themselves and students will be confused about judging themselves during the process. online learning. Then 4 teachers also experienced difficulties in asking students to provide assessments between students when online learning in Mathematics subjects, because it could not be given online, the teacher felt that in the online learning process students were very difficult for themselves, especially for judge others. From the results of the study, 3 people never made an assessment with a journal because it was difficult to apply it in the online learning process. Journals containing student notes should be made per student during the online learning process.

The observation is an assessment technique that is carried out continuously using the senses, either directly or indirectly by using guidelines or observation sheets that contain a number of behavioral indicators or observed aspects (Kunandar, 2013: 108). Self-assessment has a weakness that tends to be subjective, the data may have dishonest filling, it is possible 
for students to judge with a high score, at the time of the assessment it can occur that students carry out their best but outside the assessment there are students who are inconsistent, the results are less accurate. Kunandar, 2013). Based on the results of research conducted by Rigianti, (2020) from the affective side, teachers have difficulty in assessing. Usually, affective assessment occurs naturally when students interact, communicate, and socialize with friends. The existence of online learning eliminates the socialization of students with other students directly. So that it becomes an obstacle for teachers in conducting affective assessments.

Knowledge Competency Assessment

Table 6. Teacher Difficulties in Knowledge Assessment

\begin{tabular}{cccc}
\hline Teacher Class & \multicolumn{3}{c}{ Knowledge Assessment } \\
\cline { 2 - 4 } & Writing test & Assignment & Oral test \\
\hline III & $\sqrt{ }$ & $\sqrt{ }$ & $\sqrt{ }$ \\
IV & $\sqrt{ }$ & $\sqrt{ }$ & $\sqrt{ }$ \\
V & $\sqrt{ }$ & $\sqrt{ }$ & $\sqrt{ }$ \\
IV & $\sqrt{ }$ & & \\
\hline
\end{tabular}

Information:

Sign $\sqrt{ }=$ Difficulty

Login - = No Difficulty

Based on the results of observations and interviews, 4 classroom teachers had difficulties, because not all students took the written test, and they did not know that the written test was purely the work of students because they did not meet face-to-face with students. Furthermore, 4 teachers also experienced difficulties in providing assessments in the form of assignments during online learning in Mathematics subjects, this was because the teachers did not know, the assignments given were the results of students' work or someone helped. Based on the results of the study, 4 teachers never did an oral test, because the learning process did not use Zoom, besides that they could not make calls or video calls with WhatsApp because the students' parents were holding cellphones.

Based on the results of research conducted by Rigianti, (2020) Facts in the field show that all students get the maximum score when given a question. This becomes a question for the teacher, whether students really understand the material or students get help from adults when doing assignments. So what happens is that the teacher cannot objectively assess the learning achievement according to the students' abilities. The written test assessment aims to deepen the mastery of the knowledge competencies that have been learned or mastered in the classroom through the learning process. In giving assignments to students, the length of work time should be determined (Kunandar, 2013).

Skills Competency Assessment

Table 7. Teacher Difficulties in Skills Assessment

\begin{tabular}{cccc}
\hline Teacher Class & \multicolumn{3}{c}{ Skills Assessment } \\
\cline { 2 - 4 } & Practice & Project & Portfolio \\
\hline III & - & $\sqrt{ }$ & $\sqrt{ }$ \\
IV & $\sqrt{ }$ & - & $\sqrt{ }$ \\
V & $\sqrt{ }$ & $\sqrt{ }$ & $\sqrt{ }$ \\
IV & $\sqrt{ }$ & $\sqrt{ }$ & \\
\hline
\end{tabular}

Information:

Sign $\sqrt{ }=$ Difficulty

Login - = No Difficulty

Based on the results of observations and interviews, 3 teachers experienced difficulties in providing practical assessments, due to the lack of facilities and infrastructure, besides that it was difficult to do online learning because they did not meet face-to-face with students and 
students would find it difficult if the practice was done individually. Furthermore, 3 teachers have never conducted project assessments, because it is difficult to do if they do not meet students directly and also the material that the teacher teaches does not support other than that students will find it difficult if it is done individually. And finally, 4 teachers had difficulties in providing portfolio assessments during online learning in Mathematics. because not all students collect their work. Portfolio assessment is an ongoing assessment based on a collection of information that shows the development of students' abilities in a certain period.

The practice assessment can be used for the purpose of collecting various information about the forms of behavior or skills that are expected to appear in students (Kunandar, 2013). So that when this assessment is not carried out, the teacher will have difficulty collecting information in the learning process. While the project assessment is intended to determine the understanding, ability to apply, investigative abilities, and the ability to clearly inform students (Kunandar, 2013). This ability is difficult for students to obtain if they carry out individual project assessments due to unsupported facilities and infrastructure, especially during online learning in Mathematics.

\section{CONCLUSION}

Based on the discussion at SDN 32 Cakranegara that there are difficulties for teachers in learning planning in determining learning methods, selecting media and determining assessments. Furthermore, in the implementation of online learning the teacher has difficulties in preliminary activities in preparing students psychologically and physically and providing motivation, the core activities are observing, asking questions, exploring and collecting information and communicating. And closing activities on feedback, follow-up activities and information on subsequent activities. Then finally, in the online learning assessment in Mathematics, the teacher has difficulty in providing an assessment of attitude competence, knowledge competence so that the teacher provides a modest assessment and does not carry out several assessments, such as self-assessment, student-to-student assessments, journals, oral tests, practices, projects. and portfolio.

\section{RECOMMENDATION}

Teachers should seek more information about the difficulties faced by teachers in online learning in Mathematics, in order to conduct evaluations that generate new ideas in reducing the difficulties faced by teachers.

\section{REFERENCES}

Prastowo. A. (2015). Develop an Integrated Thematic Learning Implementation Plan (RPP). Jakarta: Prenamedia Group.

Ariesca, Y., Dewi, N. K., \& Setiawan, H. (2021). Analisis Kesulitan Guru Pada Pembelajaran Berbasis Online Di Sekolah Dasar Negeri Se-Kecamatan Maluk Kabupaten Sumbawa Barat. Progres Pendidikan, 2(1), 20-25.

Syaiful, B. (2014). Guru dan anak didik dalam interaksi edukatif.

Basri, H. (2015). Paradigma baru sistem pembelajaran. Bandung: Pustaka Setia.

Husna, R., Roza, Y., \& Maimunah, M. (2021). Identifikasi Kesulitan Guru Matematika Dalam Pelaksanaan Pembelajaran Daring di Masa Pandemi Covid-19. Jurnal Kependidikan: Jurnal Hasil Penelitian dan Kajian Kepustakaan di Bidang Pendidikan, Pengajaran dan Pembelajaran, 7(2), 428-436.

Kunandar. (2013). Penilaian Autentik. Jakarta: PT Rajagrafindo Persada.

Lailiyah, M., Umayaroh, S., \& Kartini, H. (2021). Analisis Kesulitan Guru Sekolah Dasar dalam Pembelajaran Daring di Masa Pandemi Covid-19. Jurnal Pembelajaran, Bimbingan, dan Pengelolaan Pendidikan, 1(7), 525-534.

Moleong, L. J. (2021). Metodologi penelitian kualitatif. PT Remaja Rosdakarya. 
Rahmah, N. (2018). Hakikat Pendidikan Matematika. Al-Khwarizmi: Jurnal Pendidikan Matematika Dan Ilmu Pengetahuan Alam, 1 (2), 1-10.

Rigianti, H. A., \& Prosa, P. G. S. D. (2020). Kendala Pembelajaran Daring Guru Sekolah Dasar Di Kabupaten Banjarnegara (Peer Review).

Trianto, I. B. (2014). Mendesain model pembelajaran inovatif, progresif, dan kontekstual. Jakarta: Prenadamedia Group. 